\title{
TAKSONOMI TRANSENDEN \\ (PARADIGMA BARU TUJUAN PENDIDIKAN ISLAM)
}

\author{
Ah. Zakki Fuad \\ (Dosen PAI FTK UIN Sunan Ampel Surabaya)
}

\begin{abstract}
:
The Taxonomy of the Objectives of Islamic Education in the Qur'anic Perspective. This study is initiated from a thought that "the objective of Islamic education is to make students good". The word "good" becomes the key as well as the entrance to formulate the objective of Islamic education in this study, namely by examining the concept of "good" in the Qur'an. The concept studied by using a model of thematic tafsir (mawdhu'iy) approach. With this approach the word "good" was sought through three stems, i.e., the words ahsana-yuhsinu, saluha-yasluhu and khairun with their various shapes and changes in al-Qur'an. Then the classification arranged using the theory of taxonomy. The focus of this research conducted is: How is the taxonomy of the objectives of Islamic education in the Qur'an perspective. The finding this research of the objectives of Islamic education taxonomy is called the Trancendent Taxonomy. Namely the classification of the objectives of Islamic education which is divided into three dimensions based on the Holy Qur'an, these are ilahiyyah (divinity), insaniyyah (humanity) and kauniyyah (naturality) dimensions.
\end{abstract}

Keywords: Taxonomy, Objectives of Education, Islam, dan AlQur'an 


\section{A. Pendahuluan}

Pendidikan Islam jika dipahami sebagai sebuah proses, maka diperlukan rumusan sistem dan tujuan yang baik. Hal ini disebabkan pendidikan tanpa tujuan yang jelas niscaya akan menghilangkan nilai hakiki pendidikan. ${ }^{1}$ Oleh karena itu tujuan dalam sebuah proses pendidikan merupakan unsur yang sangat penting dalam kegiatan belajar mengajar di lembaga pendidikan. Hal ini yang menjadikan semua aktifitas kependidikan, unsur dan komponen yang terlibat serta sistem pendidikan yang dibangun, semua harus diarahkan untuk mencapai hasil maksimal dalam mencapai tujuan pendidikan sesuai dengan rumusan yang telah ditetapkan.

Tujuan adalah sesuatu yang diharapkan ketika sebuah proses kegiatan itu selesai, ${ }^{2}$ sementara itu pendidikan, khususnya pendidikan Islam merupakan sebuah kegiatan yang berproses melalui tahapan-tahapan dan tingkatan, maka tujuan pendidikan itu harus sesuai dengan tahapan, klasifikasi tingkatan yang dinamis, karena tujuan pendidikan Islam bukan merupakan sesuatu benda yang berbentuk tetap dan statis, tetapi tujuan pendidikan Islam harus berkembang dinamis sesuai dengan situasi dan kondisi peserta didik dan perkembangan zaman.

Tujuan pendidikan Islam bila ditinjau dari aspek historis, maka akan mengalami dinamika seirama dengan kepentingan dan perkembangan masyarakat dimana pendidikan itu dilaksanakan. Seperti halnya tujuan pendidikan masa Nabi Muhammad SAW dengan dinamika masyarakatnya yang sederhana berbeda jauh dengan tujuan pendidikan Islam abad IV M apalagi pada abad modern saat ini. ${ }^{3}$

\footnotetext{
${ }^{1}$ M. Arifin, Ilmu Pendidikan Islam (Jakarta: Bumi Aksara, 2008), 23

2 Zakiyah Daradjat, Ilmu Pendidikan Islam (Jakarta: Bumi Aksara, 2009), 29

${ }^{3}$ Amin Abdullah, Falsafah Kalam di Era Post Modernisme (Yogyakarta: Pustaka Pelajar, 1995), 10-13.
} 
Perkembangan zaman inilah yang menyebabkan tujuan pendidikan Islam menjadi dinamis dan transformatif. Tetapi terkadang tujuan pendidikan Islam itu juga bersifat ideal-statis, dalam arti rumusannya tetap, tetapi derajat kualitasnya berubah dan berkembang. Namun yang harus digaris bawahi, bahwa tujuan pendidikan tersebut tidak boleh melepaskan diri dari nilai-nilai ilahiyyah, akibat dinamika ini, para ahli pendidikan Islam berbeda dalam menentukan rumusan pendidikan Islam. Antara para ahli satu dengan yang lain berbeda pandangan sesuai disiplin ilmunya masing-masing serta latar belakang kondisi sosial yang beragam.

Sekarang ini, tujuan pendidikan Islam banyak dirumuskan sesuai dengan keinginan guru, program institusi, kepentingan penguasa negara dan pembuat kebijakan, hasil konferensi, hasil lokakarya, hasil kongres, seminar ${ }^{4}$ atau pesanan golongan tertentu yang terkadang kurang mempertimbangkan landasan filosofis dan sumber nilai-nilai ilahiyyah dari perumusan tujuan pendidikan tersebut.

Bukti penguasa negara Indonesia bisa berpengaruh pada tujuan pendidikan adalah transformasi rumusan tujuan pendidikan sejak zaman orde lama, orde baru dan zaman reformasi sekarang ini. Rumusan tujuan pendidikan yang secara makro lebih dikenal dengan tujuan pendidikan nasional selalu mengalami perubahan yang substantif dari masa ke masa. Hal ini mengakibatkan tujuan pendidikan nasional akan selalu berubah sesuai dengan kepentingan pembuat rumusan yang akan dimasuki berbagai kepentingan-kepentingan kelompok, golongan atau legislator di pemerintahan. Bahkan

\footnotetext{
4 Seperti kongres Second World Conference on Muslim Education, International Seminar on Islamic Concepts and Curricula, Recommendation,15"to 20", March 1980, Islamabad, Seminar Pendidikan Islam se-Indonesia tangal 7-11 Mei 1960 di Cipayung, Bogor. Kegiatan ini berusaha merumuskan tujuan pendidikan Islam yang diharapkan bisa dipakai oleh lembaga pendidikan Islam.
} 
kadang memunculkan penolakan-penolakan dari kelompok tertentu dalam negara.

Persoalan-persoalan di atas menjadi dasar pentingnya kajian dalam tulisan ini, untuk mencari jawabannya dengan cara menggali langsung dari al-Qur'an. Tulisan ini menjadikan al-Qur'an sebagai pijakan dan landasan filosofis serta sumber teori untuk merumuskan tujuan pendidikan Islam, karena alQur'an memuat banyak keilmuan yang masih belum digali secara serius. Dalam hal ini penulis menggunakan metode tafsir tematik (mawdhu'iy) untuk menggali data dari ayat-ayat alQur'an.

\section{B. Pengertian Taksonomi}

Term taksonomi sebenarnya bukan khusus untuk bidang pendidikan, term taksonomi pendidikan ini baru dipopulerkan oleh Benjamin S. Bloom pada tahun $1956 \mathrm{M}$, kemudian direvisi oleh Kratwohl \& Anderson pada tahun 1964 M, dikembangkan oleh Collis and Biggs pada tahun 1982 M, ditulis dalam sebuah disertasi oleh Ghazali Mustapha pada tahun1998 M dan digunakan dalam bidang Matematika oleh Hartanto Sunardi pada tahun 2006 M. Sampai saat ini beberapa ilmuwan masih meneliti taksonomi dalam berbagai bidang termasuk bidang pendidikan.

Awalnya istilah taksonomi sudah ada sejak zaman sebelum masehi yang dikenal dengan taksonomi klasik (classical taxonomy) yang dikemukakan oleh Artistoteles pada tahun 384-322 SM. Kemudian dikembangkan pada bidang biologi oleh Charles Darwin dengan cara mengelompokkan berbagai objek kedalam kategori dan hirarki kemudian muncul dan berkembang menjadi dasar dari taksonomi biologi.

Pada bidang biologi khususnya taksonomi tumbuhan dan hewan, sudah mulai maju dan berkembang pada tahun 
1852 M, di antaranya dikemukakan oleh G.C Wittstein dalam bukunya Etymologisch Botanisches Handworterbuch yang berisi tentang taksonomi botani. Tahun 1931 M J.C. Willis dalam bukunya A Dictionary of Flowering Plants and Ferns juga telah memakai istilah taksonomi dalam memetakan sel-sel tumbuhan. ${ }^{5}$

Pada tahun 1990 M taksonomi juga dipakai dalam bidang perpustakaan digital (information retrieval system) dan sistem komputer yang dapat dipakai membantu penggunanya mencocokkan istilah dalam sistem komputer terutama dalam mengorganisasikan informasi dan dokumen. ${ }^{6}$

Islam pada dasarnya juga mengenal taksonomi sejak lama, yaitu sejak Nabi Adam as ketika diperkenalkan oleh Allah SWT tentang nama-nama benda, hewan dan tumbuhan di alam semesta. Hal ini tersirat dalam firman Allah SWT:

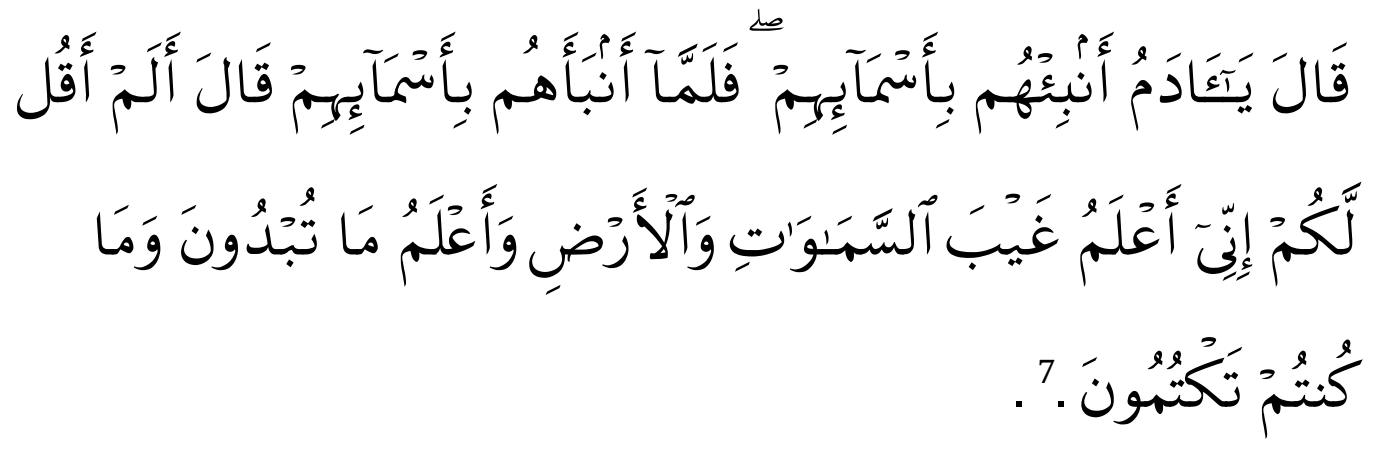

"Allah SWT berfirman: "Hai Adam, beritahukanlah kepada mereka nama-nama benda ini." Maka setelah diberitahukannya kepada mereka nama-nama benda itu, Allah berfirman: "Bukankah sudah Ku katakan kepadamu, bahwa sesungguhnya Aku mengetahui rahasia langit dan

${ }^{5}$ Gembong Tjitrosoepomo, Taksonomi Umum (Yogyakarta: UGM Press, 2005), 210.

6 Taxonomy dalam http//www.perpuspedia/ensiklopedi perpustakaan.edu. (16 Juni 2011).

${ }^{7}$ Al-Qur'an, 2:33. 
bumi dan mengetahui apa yang kamu lahirkan dan apa yang kamu sembunyikan?"."

Ayat lain yang mengandung unsur taksonomi adalah ketika Allah SWT mengajarkan Adam as nama-nama benda yanga ada di alam semesta. Firman Allah SWT:

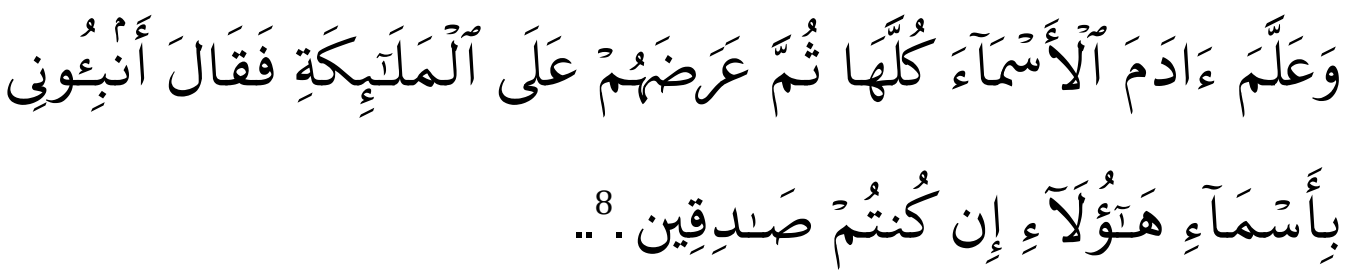

"Dan Dia mengajarkan kepada Adam nama-nama (bendabenda) seluruhnya, kemudian mengemukakannya kepada para Malaikat lalu berfirman: "Sebutkanlah kepada-Ku nama benda-benda itu jika kamu memang orang-orang yang benar".

Dua ayat di atas menyiratkan teori taksonomi yang ada dalam Islam, dimana saat itu Nabi Adam as sudah diajarkan oleh Allah SWT tentang klasifikasi benda, tumbuhan, hewan yang ada di alam semesta ini. Inilah ayat yang menjadi dasar bahwa Islam juga mengenal teori taksonomi.

Adapun makna taksonomi sendiri sangat beragam, keragaman makna tersebut secara substansi mempunyai kesamaan, yaitu ilmu tentang klasifikasi. Taksonomi diantaranya dapat diartikan sebagai klasifikasi bidang ilmu, kaidah dan prinsip yang meliputi pengklasifikasian objek, klasifikasi unsur bahasa menurut hubungan hirarkis, urutan satuan fonologis atau gramatikal yang dimungkinkan di satuan bahasa. ${ }^{9}$ Sedangkan menurut istilah ilmiah, taksonomi berarti

\footnotetext{
${ }^{8}$ Al-Qur'an, 2: 31.

${ }^{9}$ Kamus Besar Bahasa Indonesia (Jakarta: Balai Pustaka, 2005), 1125. 
unsur-unsur bahasa menurut hubungan hirarkis. ${ }^{10}$ Taksonomi juga bisa semakna dengan kategori. ${ }^{11}$

Taksonomi adalah suatu klasifikasi khusus yang berdasarkan data penelitian ilmiah mengenai hal-hal yang digolong-golongkan dalam sistematika. ${ }^{12}$ Salah satu klasifikasi khusus yang dimaksud dalam penelitian ini adalah klasifikasi tujuan-tujuan pendidikan. Tujuan (objective) pendidikan menunjukkan apa yang harus dicapai peserta didik sebagai hasil belajar yang dituangkan dalam "rumusan eksplisit untuk mengubah performa peserta didik melalui proses pendidikan". ${ }^{13}$ Di Indonesia, taksonomi yang banyak dikenal di dunia pendidikan diantaranya adalah Taksonomi Bloom, Taksonomi SOLO (Structure of Observed Learning Outcomes) serta Taksonomi Cogaff (kognitif dan afektif).

Membuat teori taksonomi berarti mengklasifikasi sebuah temuan keilmuan, memetakan, mengkategorikan dengan unsur bahasa yang bisa dipahami. Seperti klasifikasi kecil sampai besar, klasifikasi mudah sampai sulit, klasifikasi ringan sampai berat, klasifikasi lama sampai baru, klasifikasi tradisional sampai modern, klasifikasi rendah sampai tinggi, klasifikasi bawah sampai atas atau sebaliknya. ${ }^{14}$

10 M. Dahlan dkk, Kamus Induk Istilah Ilmiah (Surabaya: Target Press, 2003), 757

${ }^{11}$ Gembong Tjitrosoepomo, Taksonomi Umu,. 55 .

12 Anderson, International Encyclopedia of Teaching and Teacher Education (Oxford: Pergamon Press, 1995), 17.

${ }^{13}$ Anderson. Orin W and David R.Krathwohl, A Taxonomi for Learning, Teaching and Assassing (A Revision of Bloom's Taxonomi of Educational Objective (New York: Longman Press, 2001), 4.

${ }^{14}$ Seperti dalam taksonomi tumbuhan yang ditulis oleh Joseph Pitton de Tournefort pada tahun $1716 \mathrm{M}$ yang berjudul Institutiones Rei Herbariae yang mengklasifikasikan tumbuhan dari bawa ke atas menjadi genus (marga) familia (suku) - ordo (bangsa) - classis (kelas) - division (divisi) - regnum (dunia). Lihat Gembong Tjitrosoepomo, Taksonomi Umum, 63. 
Klasifikasi-klasifikasi yang didasarkan pada teori taksonomi itu nantinya akan disusun secara sistematis, hirarkis, kategorik sehingga bisa aplikatif dipakai untuk kebutuhan dalam merumuskan tujuan pendidikan Islam dalam perspektif al-Qur'an. Intinya tujuan pendidikan Islam yang akan ditemukan dalam penelitian ini merupakan klasifikasi data-data yang diperoleh dari al-Qur'an tentang tujuan pendidikan Islam.

\section{Taksonomi dalam Pendidikan dan Perkembangannya}

Teori taksonomi dalam dunia pendidikan keberadaannya sangat beragam, dari waktu ke waktu selalu mengalami perkembangan, hal ini disebabkan fokus kajian dan metode pendekatannya berbeda antara ilmuwan satu dengan yang lain. Berikut ini akan dijelaskan macam-macam teori taksonomi yang ada dalam dunia pendidikan sampai saat ini, yaitu:

\section{Taksonomi Bloom (Bloom's Taxonomy)}

Taksonomi pendidikan diperkenalkan oleh Benjamin S. Bloom pada tahun $\underline{1956}$ M. Menurut Bloom, tujuan pendidikan dibagi menjadi beberapa domain (ranah, kawasan) dan setiap domain tersebut dibagi kembali kedalam pembagian yang lebih rinci berdasarkan hirarkinya. Taksonomi Bloom awalnya hanya memuat ranah kognitif saja. Kemudian dikembangkan oleh Kratwohl dan Anderson pada tahun 1964 M serta Collis and Biggs pada tahun 1982 M yang pada akhirnya berkembang menjadi tiga ranah, kognitif, afektif dan psikomotorik.

Domain Kognitif meliputi: a. Pengetahuan (Knowledge), b. Pemahaman (Comprehension), c. Aplikasi (Application), d. Analisis (Analysis), e. Sintesis (Synthesis), f. Evaluasi (Evaluation). Domain Afektif terdiri dari: a. Penerimaan 
(Receiving/Attending), b. Tanggapan (Responding), c. Penghargaan (Valuing), d. Pengorganisasian (Organization), e. Karakterisasi Berdasarkan Nilai (Characterization by a Value Complex). Domain Psikomotor mengandung: a. Persepsi (Perception), b. Kesiapan (Set), c. Respon Terpimpin (Guided Response), d. Mekanisme (Mechanism), e. Respon Tampak yang Kompleks (Complex Overt Response), f. Penyesuaian (Adaptation), g. Penciptaan (Origination). ${ }^{15}$

\section{Taksonomi SOLO (Structure of Observed Learning Outcomes)}

Taksonomi SOLO (Structure of Observed Learning Outcomes) yang ditulis dan dipopulerkan oleh Biggs \& Collis tahun 1982 M adalah suatu taksonomi yang digunakan untuk mengklasifikasikan respons terhadap tugas-tugas mata kuliah mahasiswa. Taksonomi ini meliputi lima level yaitu: a. Prastruktural, b. Unistruktural, c. Multistruktural, d. Relasional, e. Abstrak lanjut (extended abstract). ${ }^{16}$

\section{Taksonomi SOLO Plus (TSP)}

Taksonomi SOLO Plus (TSP) adalah hasil temuan Hartanto Sunardi dalam Disertasi yang ditulis tahun 2006. Taksonomi SOLO Plus (TSP) ini merupakan pengembangan dan penghalusan dari taksonomi SOLO yang sudah ada sebelumnya. Taksonomi ini terdiri dari tujuh level, yaitu: a. Level 1: Prastruktural; b. Level 2: Unistruktural; c. Level 3: Multistruktural; d. Level 4: Semirelasional; e. Level 5:

\footnotetext{
15 Benyamin S. Bloom, Taksonomy of Educational Objectives, The Clasification of Educational Goals, Handbook 1 Cognitive Domain (London: Longman Group Ltd, 1979), 23-30.

${ }^{16}$ Biggs dan Collis, Evaluating the Quality of Learning; The SOLO Taxonomy (New York: Academic Press, 1982), 45.
} 
Relasional; f. Level 6: Abstrak; g. Level 7: Extended abstract. ${ }^{17}$

Kajian ini akan mengembangkan suatu taksonomi SOLO menjadi Taksonomi SOLO Plus (TSP). Pengembangan pertama dilakukan secara teoretis melalui kajian dan refleksi dari teori-teori yang ada, dan dilanjutkan secara empiris melalui penelitian kualitatif.

\section{Taksonomi Cogaff (Cognitive and Affective)}

Taksonomi ini ditulis oleh Ghazali Mustapha pada tahun 1998 dalam Disertasi di Fakulti Pengajian Pendidikan Universitas Putra Malaysia Serdang tahun 1998 yang diberi nama taksonomi cogaff. Terminologi cogaff lahir dari gabungan perkataan cognitive dan affective. Taksonomi cogaff dilahirkan berdasarkan integrasi taksonomi domain kognitif (yang dipopulerkan oleh Bloom pada tahun 1956) dan taksonomi domain afektif (yang diperkenalkan oleh Krathwohl pada tahun 1964).

Taksonomi cogaff mengambil dua domain kognitif dan afektif sebagai landasan untuk mengembangkan kecerdasan berfikir. Secara klasifikatif taksonomi cogaff disusun sebagai berikut: a. Pengetahuan, b. Kefahaman, c. Aplikasi, d. Analisis, e. Sintaksis, f. Penilaian, g. Afektif.18

\section{Taksonomi Tujuan Pendidikan Islam}

Kajian ini dimulai dari sebuah pemikiran filosofis, bahwa "Tujuan Pendidikan Islam itu harus menjadikan peserta

\footnotetext{
17 Hartanto Sunardi, "Pengembangan Taksonomi Solo menjadi Taksonomi Solo Plus (Disertasi: UNESA, Surabaya, 2006), 6.

18 Ghazali Mustapha, "Taksonomi Cogaff" (Disertasi: Fakulti Pengajian Pendidikan Universitas Putra Malaysia-Serdang, 1998), 9. 
didik menjadi baik". Kata "baik" ini adalah kunci dan pintu masuk dalam merumuskan tujuan pendidikan Islam dalam kajian ini dengan cara meneliti konsep "baik” dalam al-Qur'an.

Untuk meneliti kata "baik" dalam al-Qur'an tersebut, penulis menggunakan metode tematik (mawdhu'iy). Dengan metode ini diharapkan bisa menggali rumusan dan teorisasi tujuan pendidikan Islam yang murni bersumber dari al-Qur'an. Dengan model pendekatan tafsir tematik (mawdhu'iy) ini penulis memulai dengan cara mencari kata "baik" melalui tiga akar kata, yaitu kata ahsana-yuhsinu ( - ) dan yashluhu ( - ) serta kata khairun ( ) dengan bentuk dan perubahannya dalam al-Qur'an. Kemudian dari tiga akar kata tersebut ditelusuri lagi akar kata yang mempunyai korelasi dengan ayat lain sampai ketemu klasifikasi "baik" itu seperti apa dalam al-Qur'an. ${ }^{19}$

Kata ahsana-yuhsinu ( - ) dengan segala perubahannya dalam al-Qur'an disebut sebanyak 200 kali pada ayat dan surat yang berbeda. Sedangkan kata shaluhayashluhu ( - ) dengan berbagai bentuk dan perubahannya dalam al-Qur'an disebut sebanyak 180 kali pada ayat dan surat yang berbeda. Kata khairun ( ) terdapat dalam al-Qur'an sebanyak 109 ayat dan 39 surat yang berbeda.

Dari kata kunci di atas bisa dipahami, banyaknya kata tersebut dalam ayat dan surat berbeda telah membuktikan, bahwa al-Qur'an sangat peduli dengan ketiga term tersebut dan sangat dimungkinkan untuk dilakukan sebuah kajian yang

19 Penelusuran akar kata dalam penelitian ini menggunakan Software The Holly Qur'an versi 7.10, Harf information Tecnology co. tahun 2000 M. Afzalur Rahman, Indeks al-Qur'an (Jakarta: Amzah, 2009), Fuad Abd Baqi, Mu'jam alMufahras li alfâd al-Qur'an (Kairo: Dar al-Fikr, 1992), Fath al-Rahmān li al-Talb ay $\bar{a}$ al-Qur'ān (Surabaya: al-Hidayah, $1322 \mathrm{H}$ ) serta CD Software Maktabah alSyamilah; Akbar Mausu'ah al-Islamiyyah, Ihdhar Thani. 
dapat menghasilkan teori yang klasifikatif, sistematis dan aplikatif.

Sebenarnya selain tiga akar kata tersebut, al-Qur'an juga memakai kata "al-Birru" dan kata "al-Ma'ruf " untuk term "baik", tetapi dua kata ini tidak banyak disebut dalam al-Qur'an dan tidak signifikan untuk tema yang dikaji. Pencarian akar kata "al-Birru" dan kata "al-Ma'ruf" dengan segala perubahan dalam al-Qur'an hanya disebut kurang dari 10 ayat, itupun yang mempunyai korelasi dengan tema penelitian ini hanya pada alQur'an, 2: 177 yang substansi isinya sudah masuk pada kata "khairun".

\section{Kata Kunci ahsana-yuhsinu (أحسن- يحسن)}

Penelusuran ayat-ayat al-Qur'an melalui akar kata ahsana-yuhsinu dengan segala perubahannya terdapat 200 ayat pada surat dan ayat yang berbeda. Kemudian ayat-ayat tersebut dikaji dan ditemukan setidaknya ada beberapa ayat yang mempunyai hubungan dengan tema yang dikaji. Kajian ayat-ayat tentang "baik" dengan akar kata ahsana-yuhsinu beserta indikator atau ciri-ciri orang yang berbuat baik (muhsinin) yaitu:

\section{a. Al-Qur'an, 2: 195:}

Indikator orang baik/perbuatan baik yaitu: Infak di jalan Allah, menyembah Allah, berperilaku positif (keyakinan atas keesaan Allah, kemerdekaan, kebebasan, ketenangan hidup lahir batin).

\section{b. Al-Qur'an, 2: 195:}

Indikator orang baik/perbuatan baik yaitu: Ikhlas, menjalankan perintah Allah, menjauhi larangan Allah.

\section{c. Al-Qur'an, 5: 13:}

Indikator orang baik/perbuatan baik yaitu: Memaafkan (membalas keburukan dengan kebaikan). 


\section{d. Al-Qur'an, 5: 93:}

Indikator orang baik/perbuatan baik yaitu: Beriman, bertqwa, beramal saleh.

e. Al-Qur'an, 11: 115:

Indikator orang baik/perbuatan baik yaitu: Salat, istikamah, sabar.

\section{Kata Kunci Shaluha-yaṣluhu (صلح- يصلح)}

Kata shaluha-yashluhu (صلح- يصلح) dengan berbagai bentuk dan perubahannya dalam al-Qur'an disebut 180 kali pada ayat dan surat yang berbeda. Sedangkan yang mempunyai korelasi dengan tujuan pendidikan Islam adalah:

\section{a. Al-Qur'an, 2: 11:}

Indikator orang baik/perbuatan baik yaitu: Tidak membuat kerusakan di bumi.

\section{b. Al-Qur'an, 3: 114:}

Indikator orang baik/perbuatan baik yaitu: Iman kepada Allah, iman kepada hari akhir, menyuruh berbuat baik, mencegah kemungkaran, cepat dalam melaksanakan kebaikan, membaca al-Qur'an di malam hari.

\section{c. Al-Qur'an, 9: 75:}

Indikator orang baik/perbuatan baik yaitu: Sedekah dan silaturahmi.

\section{Kata Kunci Khairun (خير)}

Kata khairun (خير ) terdapat dalam al-Qur'an sebanyak 109 ayat dan 39 surat yang berbeda. Dari 109 ayat yang dikaji, ditemukan setidaknya ada beberapa ayat yang mempunyai hubungan (munasabat) dengan tujuan pendidikan Islam sebagai berikut: 
a. Al-Qur'an, 2: 184:

Indikator orang baik/perbuatan baik yaitu: Ikhlas mengerjakan kebaikan, berpuasa.

b. Al-Qur'an, 2: 215

Indikator orang baik/perbuatan baik yaitu: Memberi nafkah kepada anak an keluarganya.

c. Al-Qur'an, 2: 220:

Indikator orang baik/perbuatan baik yaitu: Peduli dengan anak yatim.

d. Al-Qur'an, 2: 263:

Indikator orang baik/perbuatan baik yaitu: Selalu berkata dengan baik, pemaaf.

e. Al-Qur'an, 2: 271:

Indikator orang baik/perbuatan baik yaitu: Bersedekah kepada fakir miskin.

f. Al-Qur'an, 4: 25:

Indikator orang baik/perbuatan baik yaitu: Sabar dalam menerima cobaan dari Allah.

g. Al-Qur'an, 4: 59:

Indikator orang baik/perbuatan baik yaitu: Selalu berpegang teguh pada Al-Qur'an dan Hadis Nabi Muhammad SAW.

h. Al-Qur'an, 4: 114:

Indikator orang baik/perbuatan baik yaitu: Bersedekah, amar ma'ruf, selalu berdamai dengan sesama manusia.

i. Al-Qur'an, 7: 85:

Indikator orang baik/perbuatan baik yaitu: jujur dalam transaksi, tidak merusak alam dan kehidupan yang ada di bumi.

j. Al-Qur'an, 9: 3:

Indikator orang baik/perbuatan baik yaitu: Bertaubat atas segala dosa dan kesalahan. 


\section{k. Al-Qur'an, 9: 41:}

Indikator orang baik/perbuatan baik yaitu: Jihad dengan harta dan jiwa.

\section{l. Al-Qur'an, 24: 60:}

Indikator orang baik/perbuatan baik yaitu: Sopan santun dalam berpakaian.

Data-data dari ayat-ayat al-Qur'an yang mempunyai korelasi (munasabat) tersebut kemudian dilakukan unitizing, reducing, inferring dan analyzing. Unitizing terhadap data-data tersebut dilakukan dengan cara menyatukan dan mengelompokkan berdasarkan tema dan kebutuhan penelitian kemudian di reducing dengan merangkum dan memilih datadata yang dibutuhkan dan dilanjutkan dengan inferring atau menarik sebuah kesimpulan. Setelah dilakukan inferring diakhiri dengan analyzing atau menganalisis, menilai data yang telah direduksi sesuai dengan kontek penelitian dan mendiskripsikan secara eksplisit menjadi sebuah teori.

Hasil dari unitizing, reducing dan analyzing terhadap temuan data-data berupa ayat-ayat al-Qur'an tersebut kemudian diklasifikasi (taksonomi) sesuai dengan karakteristiknya menjadi tiga kategori. Pertama, "baik" dalam kaitannya dengan hubungan manusia dengan Tuhan oleh penulis dinamakan dengan dimensi ilahiyyah (ketuhanan/ teosentris). Kedua, "baik" dalam kaitannya dengan hubungan manusia dengan manusia dan interaksi sosial dimasyarakat dinamakan dengan dimensi insaniyyah (kemanusiaan/ antroposentris). Ketiga, "baik" dalam kaitannya dengan hubungan manusia dengan alam semesta yang dinamakan dengan dimensi kauniyyah (alam semesta/ekosentris).

Dimensi ilahiyyah (ketuhanan) adalah tujuan pendidikan Islam yang harus dicapai setelah mengikuti 
kegiatan belajar mengajar (KBM) yang mengandung hubungan antara manusia dengan Tuhannya. Dimensi insaniyyah (kemanusiaan) merupakan tujuan pendidikan Islam yang harus dicapai setelah mengikuti kegiatan belajar mengajar (KBM), di dalamnya memuat bagaiman mengatur hubungan manusia dengan dengan manusia yang lain, bagaimana cara berinteraksi sosial yang baik antara manusia dengan masyarakatnya. Sedangkan dimensi Kauniyyah (alam semesta) adalah tujuan pendidikan Islam yang harus dicapai setelah mengikuti kegiatan belajar mengajar (KBM) yang mengandung hubungan antara manusia dengan alam semesta.

Temuan tiga dimensi ini kemudian dinamakan dengan Taksonomi Transenden (Trancendent Taxonomy). Tiga dimensi tersebut diklasifikasi menjadi tujuan pendidikan Islam sesuai dengan teori taksonomi sebagai berikut:

\section{Dimensi Ilahiyyah (Ketuhanan-Teosentris):}

a. Beriman (kepada Allah, Malaikat, Kitab Allah, Rasul Allah, Hari akhir, kada \& kadar)

b. Bertakwa (Beribadah, berzikir, berpuasa, bersukur, adil)

c. menyembah Allah

d. Menjalankan perintah Allah

e. Menjauhi laranan Allah

f. Salat (Sunah: tahajud, witir, rawatib, duha, tarawih, istisqa', gerhana, jenazah. Idul fitri, idul adha, tahiyat almasjid. Wajib: Isya', subuh, duhur, asyar, maghrib).

g. Puasa (Wajib: Ramadhan, nazar. Sunah: Senin-kamis, tarwiyah-arafah, 6 hari bulan syawal).

h. Berpegang teguh pada al-Qur'an dan Hadis

i. Membaca al-Qur'an di malam hari

j. Jihad dengan harta dan jiwa, beramal saleh, ikhlas, sabar, tobat). 

k. Beramal saleh
l. Ikhlas
m. Sabar
n. Tobat

\section{Dimensi Insaniyyah (Kemanusiaan-Antroposentris)}

a. Sedekah di jalan Allah (fakir, miskin, amil, mualaf, budak, gharim, sabilillah, ibnu sabil).

b. Infak di jalan Allah (Ibu, bapak, kerabat, anak yatim, orang miskin, sabilillah).

c. Peduli kepada anak yatim

d. Silaturahmi

e. Berdamai dengan manusia

f. Jujur dalam bertransaksi

g. Cepat dalam melaksanakan kebaikan

h. Berprilaku positif

i. Pemaaf

j. Berkata baik

k. Sopan santun dalam berpakaian

\section{Dimensi Kauniyyah (Alam -Ekosentris)}

a. Tidak merusak bumi (daratan, tanah, lautan, air, hewan, ikan, tumbuhan, tanaman)

b. Tidak merusak alam (matahari, bulan, bintang, awan, hujan).

Tiga dimensi tersebut akan diskema sesuai dengan teori taksonomi di bawah ini: 
Ah. Zakki Fuad

Taksonomi 1: Dimensi Ilahiyyah (Ketuhanan)

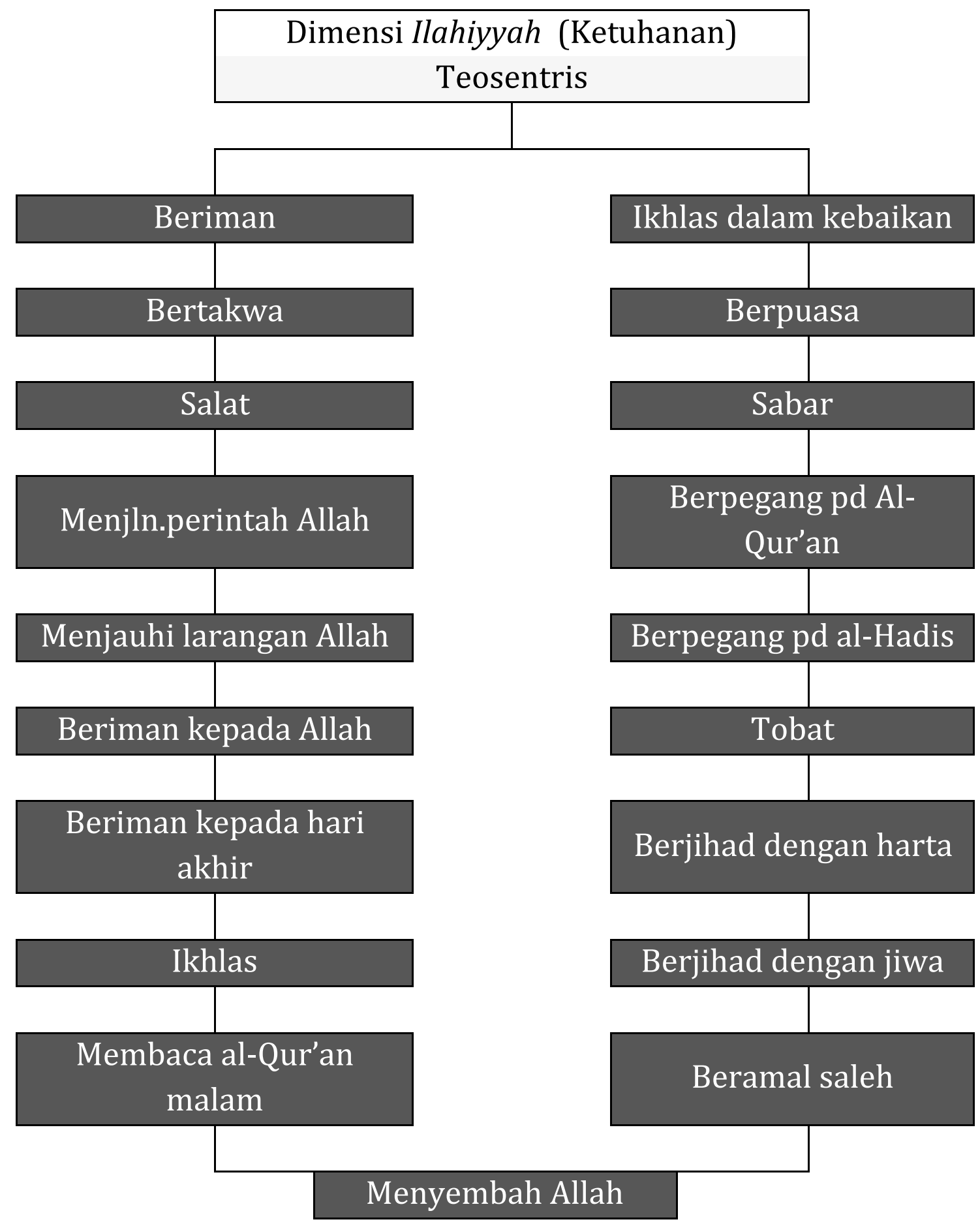

Jurnal Pendidikan Agama Islam Volume 02 Nomor 01 Mei 2014

Hal $18-25$ 
Taksonomi Transenden (Paradigma Baru Tujuan Pendidikan Islam)

Taksonomi 2;

Dimensi Insaniyyah (Kemanusiaan)

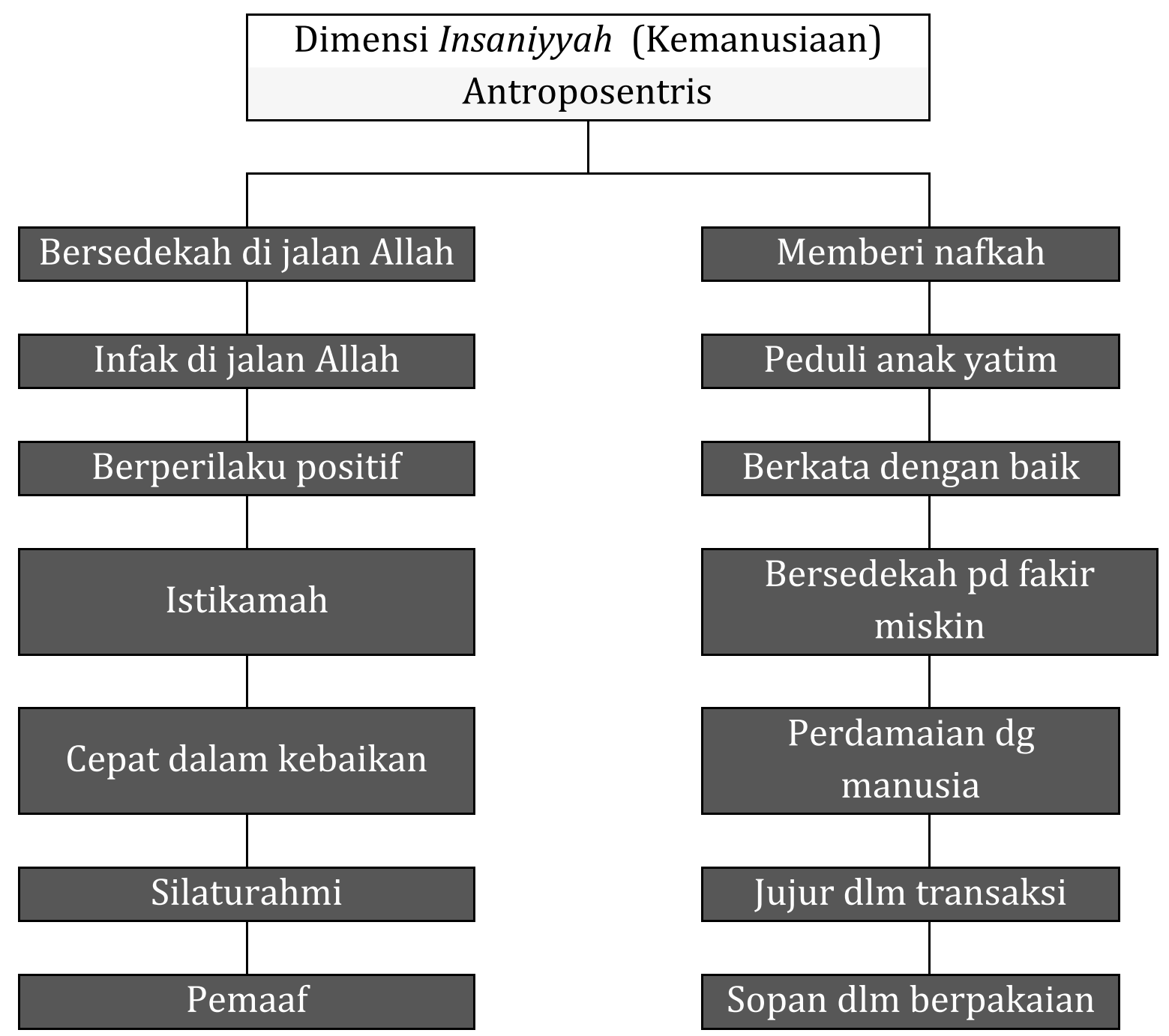


Ah. Zakki Fuad

Taksonomi 3

Dimensi Kauniyyah (Alam Semesta)

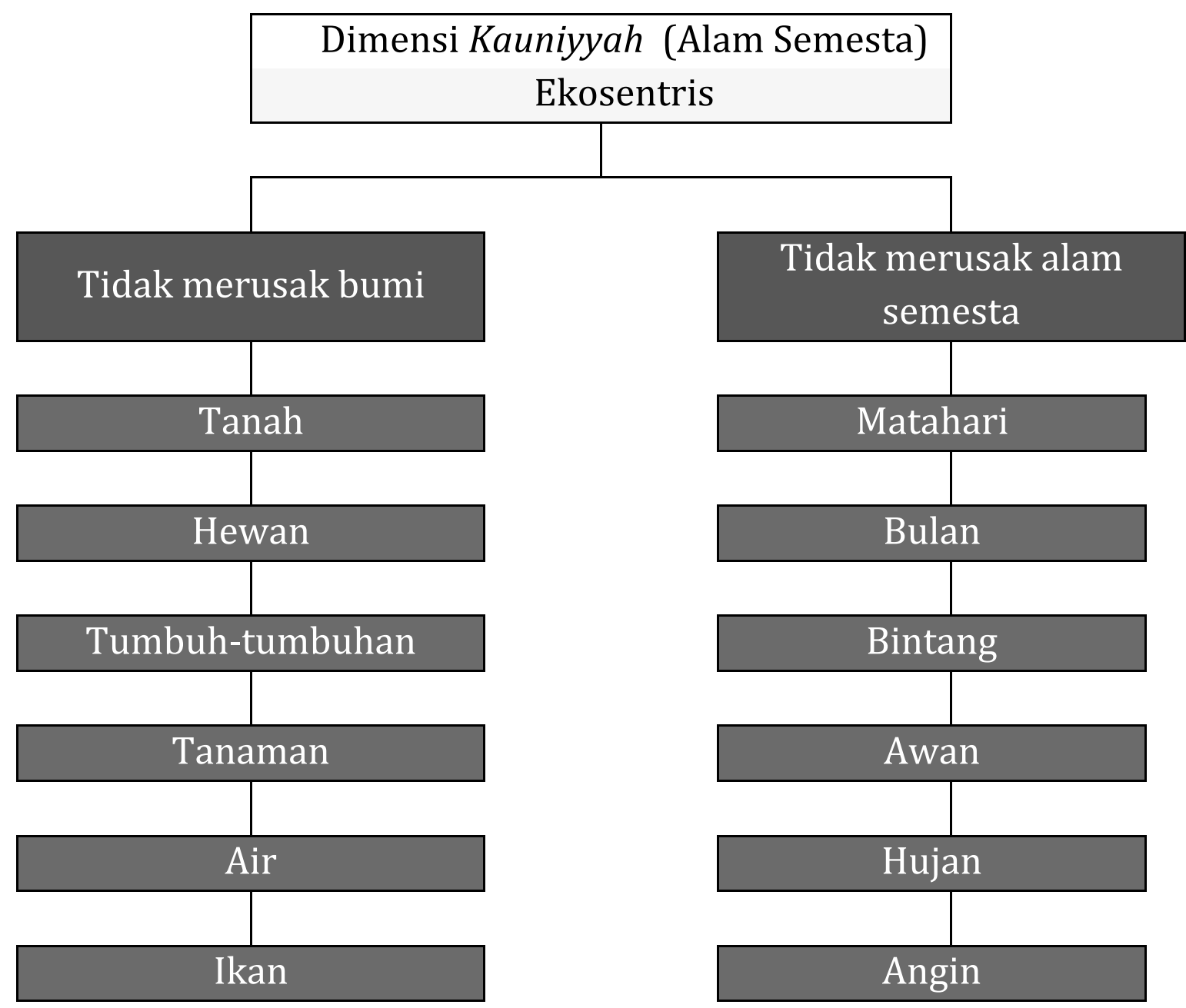


Taksonomi 4;

Taksonomi Tujuan Pendidikan Islam Perspektif al-Qur'an

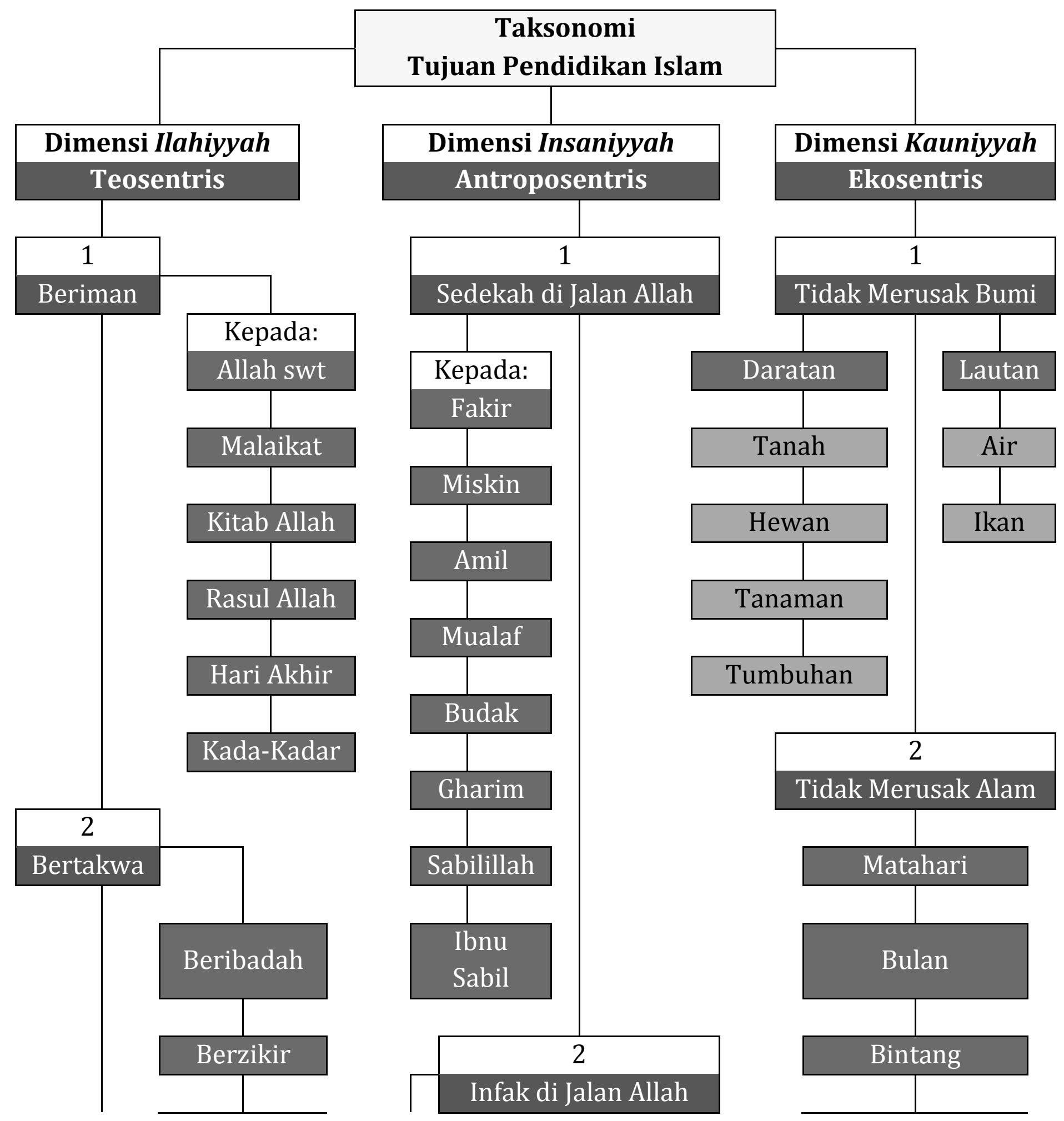


Ah. Zakki Fuad

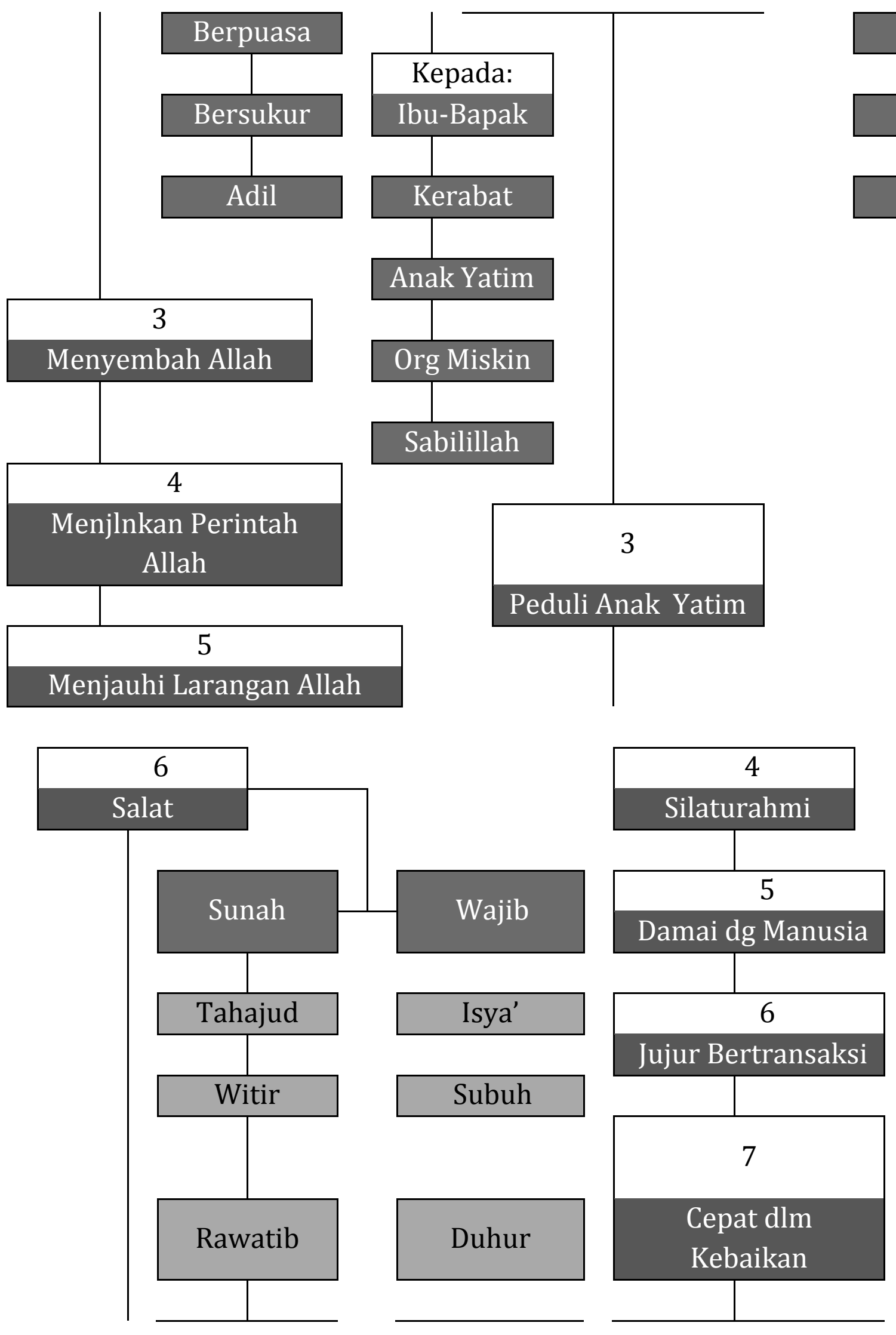

Jurnal Pendidikan Agama Islam

Volume 02 Nomor 01 Mei 2014

Hal $22-25$ 
Taksonomi Transenden (Paradigma Baru Tujuan Pendidikan Islam)

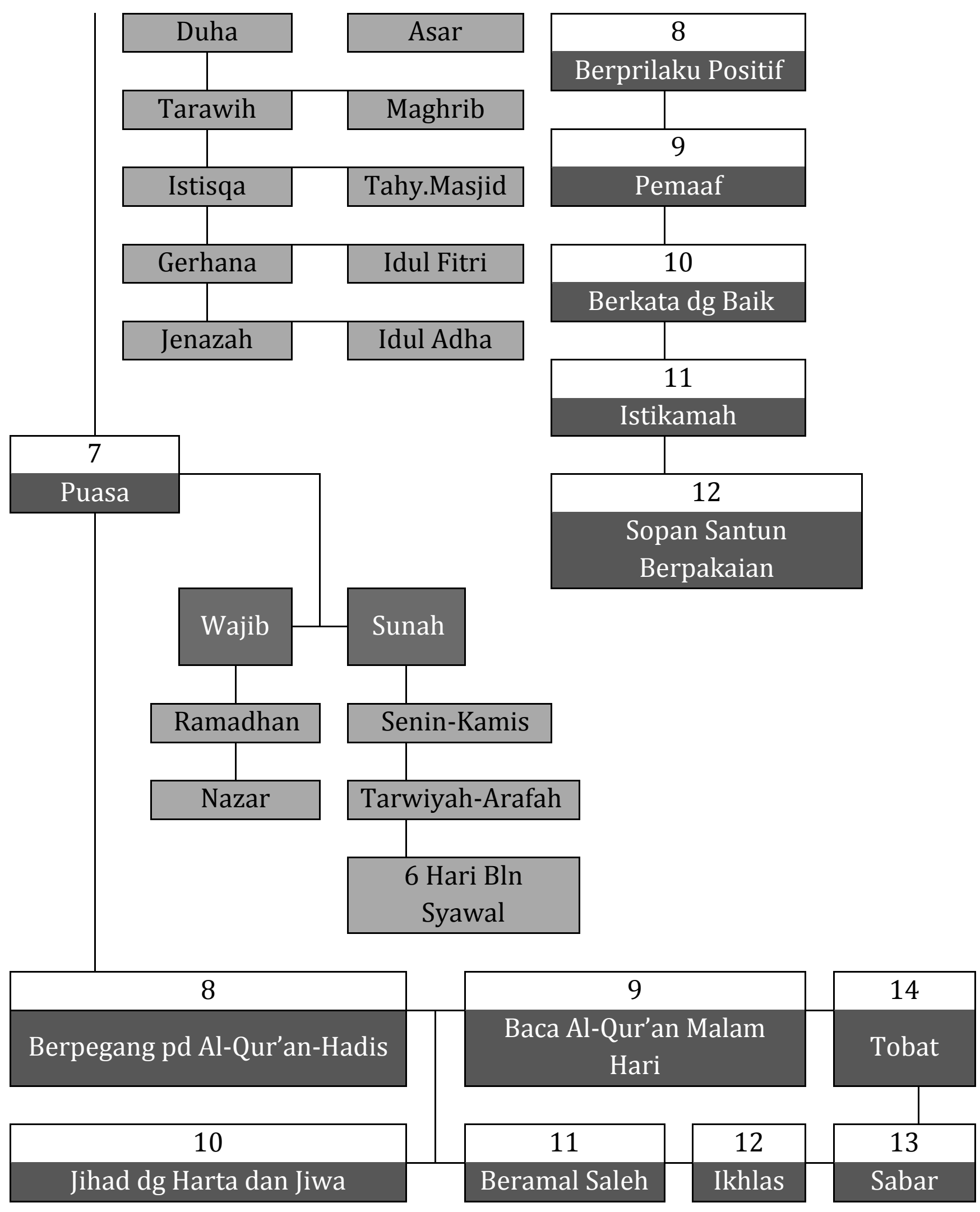




\section{E. Penutup}

Hasil kajian tentang taksonomi tujuan pendidikan Islam dalam perspektif al-Qur'an dengan menggunakan pendekatan tafsir tematik (maudhu'iy) menemukan sebuah teori tentang tujuan pendidikan Islam yang dinamakan dengan Taksonomi Transenden (Trancendent Taxonomy) yaitu tujuan pendidikan Islam yang terdiri dari tiga dimensi; Dimensi ilahiyyah/ teosentris/ ketuhanan, dimensi insaniyyah/ antroposentris/ kemanusiaan, dimensi kauniyyah/ ekosentris/ alam semesta.

Dimensi ilahiyyah (ketuhanan) adalah tujuan pendidikan Islam yang harus dicapai setelah mengikuti kegiatan belajar mengajar yang mengandung hubungan antara manusia dengan Tuhannya. Dimensi insaniyyah (kemanusiaan) merupakan tujuan pendidikan Islam yang harus dicapai setelah mengikuti kegiatan belajar mengajar yang di dalamnya memuat bagaiman mengatur hubungan manusia dengan manusia yang lain, bagaimana cara berinteraksi sosial yang baik antara manusia dengan masyarakatnya. Sedangkan dimensi Kauniyyah (alam semesta) adalah tujuan pendidikan Islam yang harus dicapai setelah mengikuti kegiatan belajar mengajar yang mengandung hubungan antara manusia dengan alam semesta. 


\section{DAFTAR PUSTAKA}

Abdurrahman Saleh Abdullah, Educational Theory a Quranic Outlook (Jakarta: Rineka Cipta, 2005).

Atiyah Al-Abrasyi, Dasar-dasar dan Pokok Pendidikan Islam (Jakarta: Bulan Bintang, 1998).

Afzalurrahman, Indeks al-Qur'an (Jakarta: Amzah, 2009).

Anderson, International Encclopedia of Teaching and Teacher Education (Oxford: Pergamon Press, 1995).

Abd Hayy Farmawi, Al-Bidayah fi al-Tafsir Maudhu'i, terj. Suryan A.

J. (Jakarta: Raja Grafindo, 1996).

Amin Abdullah, Falsafah Kalam di Era Post Modernisme (Yogyakarta: Pustaka Pelajar, 1995).

Arifin, Ilmu Pendidikan Islam (Jakarta: Bumi Aksara, 2008).

Anton Bakker, Metodologi Penelitian Filsafat (Yogyakarta: Kanisius, 1992).

Benyamin S. Bloom, Taksonomy of Educational Objectives, The Clasification of Educational Goals, Handbook 1 Cognitive Domain (London: Longman Group Ltd., 1979).

Fuad Abdul Baqi, Mu'jam al-Mufahras li Alfâd al-Qur'an (Kairo: Dar al-Fikr, 1992).

J. Biggs \& Collis, K. F., Evaluating the Quality of Learning: The SOLO Taxonomy (New York: Academic Press, 1982).

Klass Krippendorff, Analisis Isi Pengantar Teori dan Metodologi, terj. Farid Wajidi (Jakarta: Raja Grafindo, 1993).

Orin W Anderson and David R. Krathwoh, A Taxonomi for Learning, Teaching and Assassing (A Revision of Bloom's Taxonomi of Educational Objective (New York: Longman Press, 2001).

Zakiyah Daradjat, Ilmu Pendidikan Islam (Jakarta: Bumi Aksara, 2009).

Al-Bidayah fi al-Tafsir Maudhu'i, Dirasah Manhajiyyah Maudu'iyyah, terj. Rosihan Anwar (Bandung, 2002). 